\title{
EFEKTIFITAS MOTIVASI PADA LOKAL BIROKRASI
}

\author{
Singgih Tiwut Atmojo ${ }^{1}$, Priskila ${ }^{2}$ \\ ${ }^{1}$ STIE Mulia Singkawang \\ Email: singgihatdmodjo3805@gmail.com \\ ${ }^{2}$ STIE Mulia Singkawang \\ Email: priskilaoyne@gmail.com
}

\begin{abstract}
Tujuan penelitian ini adalah untuk mengetahui pengaruh motivasi yang diberikan terhadap kinerja pegawai dilingkungan Dinas Penanaman Modal dan Tenagakerja Kota Singkawang. Metode penelitian ini menggunakan metode deskriptif dalam bentuk survei sedangkan teknik pengumpulan data melalui observasi, menyebarkan kuisioner dengan jumlah sampel yang diambil yaitu sebanyak 42 responden. Analisis menggunakan SPSS V25. Berdasarkan hasil penelitian hasil uji parsial (t) menyatakan bahwa variabel motivasional berpengaruh terhadap kinerja dengan nilai signifikan 0.010 dibawah 0,05 dan variabel higienis juga berpengaruh signifikan terhadap kinerja dengan nilai signifikan 0,029 dibawah 0,05.
\end{abstract}

\section{Kata kunci: Motivasi, Kinerja}

This study aims to determine the effect of motivation given on employee performance in the Investment and Labor Office of Singkawang City. This research method uses descriptive method in the form of a survey while the technique of collecting data through observation, distributing questionnaires with a total sample of 42 respondents. Analysis using SPSS V25. Based on the results of the partial test $(t)$ states that motivation variables affect performance with a significant value of 0.010 below 0.05 and hygienic variables also have a significant effect on performance with a significant value of 0.029 below 0.05 .

Keywords-Motivation, Performance

(C) 2019 JBTI. All rights reserved

Article History : Received: 2019-10-28; Revised: 2019-11-05; Accepted: 2019-11-12

\section{PENDAHULUAN}

Persaingan merupakan satu hal yang dihadapi oleh perusahaan, salah satunya yaitu persaingan sumber daya manusia yang dimiliki oleh perusahaan, tidak hanya persaingan sumber daya manusia, kemantapan perusahaan dalam mengelola aset yang dimiliki juga berpengaruh. Tidak hanya dalam dunia bisnis dalam organisasi kepemerintahan sumber daya manusia juga harus diperhatikan. Karena manusia tidak lagi dianggap sebagai faktor produksi tetapi lebih dianggap sebagai asset organisasi yang penting. Keefektifan dan keunggulan organisasi sangat bergantung pada kualitas sumber daya manusia yang dimiliki. Selain itu,tentu saja setiap organisasi menginginkan tenaga kerja yang memiliki kualitas yang baik, maka organisasi juga harus memperlakukan mereka dengan baik dan memanfaatkannya dengan sebaik mungkin. Kualitas sumber daya manusia dalam suatu organisasi diharapkan mampu meningkatkan kinerja organisasi, hal tersebut dapat dipengaruhi juga oleh motivasi yang diberikan pada lingkungan kerjanya. 
Dinas Penanaman Modal dan Katenagakerjaan Kota Singkawang merupakan instansi kepemerintahan yang memberikan pelayanan kepengurusan perizinan, kepengurusan tenaga kerja dan kepengurusan investasi. Sangat menyadari pentingnya faktor sumber daya manusia karena sumber daya manusia merupakan faktor penting dalam keberhasilan pengelolaan organisasi.

Berkaitan dengan motivasi kerja, pengembangan sumber daya manusia menjadi isu yang sangat penting. Karena dengan adanya pengembangan sumber daya manusia akan mampu memberikan reaksi bagi pegawai agar termotivasi untuk bekerja. Faktor yang mempengaruhi motivasi kerja pegawai menurut Herzberg dalam Usman (2008) teori dua faktor, pertama yaitu faktor motivasional atau daya dorong yang timbul dari dalam diri masing-masing pegawai, faktor kedua yaitu higienis atau berupa daya dorong yang datang dari luar diri pegawai terutama dari organisasi /lembaga tempatnya bekerja. Daya dorong dari luar diri pegawai salah satunya bisa berupa kondisi lingkungan kerja sebagai penunjang saat bekerja. Menurut teori Herzberg's dualfaktor theory of job satisfaction and motivation satisfier berhubungan dengan sifat pekerjaan itu sendiri. Faktorfaktor dari satisfier disebut juga dengan faktor intrinsik. Sedangkan faktor dissatisfier, terkait dengan hubungan individual terhadap konteks atau lingkungan dimana mereka bekerja, yang terpenting adalah company policy and administration, yang menyebabkan inefektif dan inefisiensi dalam organisasi, urutan kedua adalah ketidakmampuan teknis dari supervisisupervisi yang tidak mempunyai pengetahuan memadai tentang pekerjaannya, kemudian salary, lack of recognition and achievement juga dapat memunculkan ketidakpuasan. Herzberg berpendapat bahwa apabila para manajer ingin memberikan motivasi pada bawahannya, yang perlu ditekankan adalah faktor-faktor yang menimbulkan rasa puas,yaitu dengan mengutamakan faktorfaktor motivasional yang bersifat internal (Noermijati 2010).

Motivasi intrinsik (Motivational) adalah sebuah dorongan yang membentuk perilaku yang menunjukkan prestasi atau kinerja. Deci, Koestner \& Ryan (1999), dalam penelitian Zapata-Phelan, et. al., (2009) menyebutkan bahwa motivasi intrinsik muncul ketika me-lakukan tugas dan menjadikannya sebagai penghargaan pribadi, mengacu kepada rasa kesenangan dan kebahagian. Motivasi intrinsik melibatkan pengalaman afeksi positif saat suatu pekerjaan diselesaikan (ZapataPhelan, et. al., 2009). Pada hakekatnya karyawan termotivasi dengan demikian lebih mungkin untuk mengeksplorasi jalur baru dan mengambil resiko yang lebih besar, (Amabile, Goldfarb \& Brackfield, 1990). Selain itu, motivasi intrinsik adalah motivasi yang berasal dari dalam individu, bukan dari imbalan eksternal, seperti uang atau nilai. Warr, et. al (1979) telah mendefinisikan motivasi intrinsik sebagai sejauh mana sese-orang ingin bekerja bersinar dalam pekerja-annya untuk mendapatkan kepuasan intrinsik. Mereka menemukan hubungan antara konstruk ini dan secara keseluruhan ke-puasan kerja karyawan. Motivasi ekstrinsik adalah motivasi yang bersumber dari luar diri yang turut menentukan perilaku seseorang dalam kehidupan seseorang yang dikenal dengan teori hygiene factor. Menurut Herzberg yang dikutip oleh Luthans (2011), yang tergolong sebagai hygiene factor antara lain quality supervisor, interpersonal relation, working condition. Motivasi ekstrinsik merupakan faktor eksternal diluar karyawan yang dapat mempengaruhi motivasi karyawan, hal ini sesuai dengan hasil penelitian yang dilakukan oleh Lee \& Kulviwat (2008) yang menyebutkan bahwa motivasi intrinsik dan ekstrinsik berpengaruh secara khusus menghadirkan dukungan empiris untuk keunggulan loyalitas sebagai alat motivasi dalam budaya kerja kolektif untuk mencapai komitmen organisasi.

Pegawai yang sudah melalui tahap pengembangan akan menghasilkan kinerja yang optimal, jika didukung pula oleh kompensasi yang memadai. Tidak hanya itu pegawai yang mempunyai motivasi dan berprestasi akan sangat menyukai tantangan dan berusaha untuk bekerja sebaik mungkin untuk mencapai tujuan organisasi, jadi sudah dapat disimpulkan bahwa pegawai tersebut memiliki tanggungjawab yang baik dengan didukung oleh kinerja yang dimilkinya. Salah satu faktor yang mempengaruhi motivasi kerja adalah disiplin kerja, disiplin yang baik dijalankan melalui peraturan yang diterapkan maupun dari kesadaran karyawan sendiri akan mempengaruhi kinerja perusahaan. Menurut Luviansi dalam penelitianya (Analisis Pengaruh Motivasi Terhadap Prestasi Kerja Melalui Kepuasan Dan Disiplin Kerja Pegawai Studi Pada Universitas Palangka 
Raya, Jurnal Sains Manajemen Vol 1 No 1 2012), menjelaskan bahwa motivasi yang baik dapat meningkatkan disiplin kerja kepuasan kerja dapat ditingkatkan melalui motivasi kerja yang dicerminkan dari dua dimensi yaitu, faktor pemeliharaan dan faktor motivasi. Dimensi pemeliharaan ditunjukan oleh suasana kenyamanan pada saat melaksanakan pekerjaan sehingga dapat memberikan hasil yang optimal, pegawai memiliki hubungan personal yang baik dengan atasan maupun rekan kerja, status pekerjaan dan mutu penyeliaan yang baik. Sedangkan dimensi faktor motivasi ditunjukan oleh keinginan individu pegawai dalam mencapai prestasi, bertanggung jawab, adanya peluang untuk maju dan adanya kemungkinan untuk berkembang. Setiap diri individu pastinya memiliki motivasi untuk meningkatkan kepuasan kerja, namun tidak setiap diri individu yang memiliki kesempatan untuk mencapai kepuasan kerja. Kemampuan motivasi mempengaruhi disiplin kerja masuk dalam kategori rendah karena tidak semua kedisiplinan yang dapat dijalani pegawai, salah satunya adalah dalam hal kemampuan untuk mentaati peraturan jam kerja kantor sehingga kedisiplinan pegawai rendah.

Untuk mengetahui tingkat disiplin kerja pegawai pada Dinas Tenaga Kerja dan Penanaman Modal Kota Singkawang dapat dilihat pada table 1 berikut ini:

Tabel 1

Tingkat Absensi

\begin{tabular}{|c|c|c|c|c|c|c|c|c|}
\hline \multirow{2}{*}{$\begin{array}{c}\text { Triwulan } \\
2018\end{array}$} & \multirow{2}{*}{$\begin{array}{c}\text { Jumlah } \\
\text { pegawai }\end{array}$} & \multirow{2}{*}{$\begin{array}{c}\text { Hari } \\
\text { kerja }\end{array}$} & $\begin{array}{c}\text { Jumlah } \\
\text { hari } \\
\text { pegawai } \\
\text { kerja }\end{array}$ & \multicolumn{2}{|c|}{ Tingkat Absensi } & \multicolumn{3}{|c|}{$\begin{array}{c}\text { Jumlah } \\
\text { Absensi }\end{array}$} \\
\cline { 5 - 10 } & & & Sakit & Ijin & Alpa & Total & $\%$ \\
\hline I & 46 & 66 & 3036 & 8 & 10 & - & 18 & 0,59 \\
II & 46 & 66 & 3036 & 8 & 20 & - & 28 & 0,92 \\
III & 46 & 66 & 3036 & 11 & 14 & - & 25 & 0,82 \\
IV & 46 & 66 & 3036 & 21 & 20 & - & 41 & 1,35 \\
\hline
\end{tabular}

Sumber: Dinas Tenaga Kerja dan Penanaman Modal Kota Singkawang 2018

Dari Tabel 1 diatas dapat ditarik kesimpulan bahwa setiap triwulan persentase ketidakhadiran pegawai terus meningkat dengan keterangan absensi yaitu sakit dan ijin tetapi lebih didominankan oleh absensi ijin dengan persentase yang sangat tinggi diantara absensi sakit maupun alpa.

Kinerja pada dasarnya merupakan hasil kerja yang telah dicapai oleh pegawai dalam melaksanakan tugasnya sesuai dengan tanggungjawab yang diberikan kepadanya. Dalam hal ini pegawai dapat belajar seberapa besar kinerja mereka, melalui sarana informasi seperti komentar dari atasan maupun rekan sekerja. Kinerja erat kaitanya dengan motivasi menurut Gibson dalam Rivai (2009) menjelaskan bahwa salah satu faktor yang mempengaruhi kinerja adalah dorongan atau motivasi. Karyawan atau pegawai akan meningkat kinerjanya jika ada dorongan maupun motivasi yang diberikan baik itu faktor motivasional maupun faktor higine, untuk itu perlu diperhatikan tentang efektifitas dari motivasi yang diberikan karena tidak semua karyawan atau pegawai menginginkan pendekatan motivasi yang seragam melainkan menyesuaikan dengan kemampuan serta kebutuhan masing-masing pegawai. Sehingga nantinya pendekatan motivasi yang dipilih mampu meningkatkan efektifitas serta kinerja dari para pegawai. Berdasarkan uraian diatas, maka penulis tertarik untuk melakukan penelitian dengan judul "Efektifitas Motivasi Pada Lokal Birokrasi". Maka rumusan masalah penelitian ini adalah Apakah motivasi yang diberikan mempunyai pengaruh terhadap kinerja pegawai dilingkungan Dinas Penanaman Modal dan Ketenagakerjaan Kota Singkawang? Batasan penelitian ini adalah penelitian yang dilakukan tidak meluas dan tetap mengarah pada tujuan yang diinginkan, maka penulis membatasi masalah yang diteliti dengan variabel yang diteliti yaitu motivasi dua faktor Hezberg (faktor motivasional, faktor higienis) dan variable kinerja. 


\section{Pengaruh Faktor Motivasional Terhadap Kinerja}

Menurut Herzberg dikutip Luthans (2011), yang tergolong sebagai fakktor motivasional antara lain Achievement (Keberhasilan), Recognition (Pengakuan/Penghargaan), Work it self (Pekerjaan itu sendiri), Responsibility (Tanggungjawab) dan Advencement (Pengembangan). Penelitian Hayati \& Caniago (Islamic Work Ethic: The Role of Intrinsic Motivation, Job Satisfaction, Organi-zational Commitment and Job Perfor-mance. Procedia - Social and Behavioral Sciences 65, 2012), menemukan pengaruh antara motivasi intrinsik dan komitmen organisasi. Motivasi yang timbul dari dalam diri seorang guru, akan memper-lihatkan kesemangatan mereka dalam bekerja sehingga memupuk sikap komitmen yang tinggi yang berujung pada peningkatan kinerja. Akan tetapi hasil berbeda tentang pengaruh motivasi intrisik pada penelitian Muslih (Analisis Pengaruh Motivasi terhadap Kepuasan Kerja dan Kinerja Pegawai di PT Sang Hyang Seri (Persero) Regional III Malang, Jurnal Aplikasi Manajemen Vol 10 No 4, 2012) motivasi instriksik tidak berpengaruh terhadap kinerja pegawai, yang berarti peningkatan ataupun penurunan tingkat motivasi intrinsik pegawai tidak memberikan pengaruh terhadap kinerja pegawai. Hal ini merupakan variasi dari hasil penelitian terdahulu yang memicu pertanyaan dan akan diteliti dalam penelitian kali ini, oleh karena itu dalam penelitian ini diajukan hipotesis pertama yaitu:

H1 : Faktor Motivasional Berpengaruh Terhadap Kinerja

\section{Pengaruh Faktor Higienis Terhadap Kinerja}

Pada hipotesis kedua bertujuan untuk melihat pengaruh motivasi ekstrisik (higie) terhadap kinerja. Motivasi karyawan merupakan hal yang sangat penting bagi kehidupan suatu organisasi terutama peningkatan kinerja secara optimal (Slocum dalam Sujak, 1990). Sejalan dengan yang ditemukan oleh Purnomowati (Analisis Pengaruh Motivasi terhadap Kepuasan Kerja dan Kinerja Karyawan dengan Variabel Moderator Komitmen pada Perusahaan Garmen di Surabaya. Jurnal Fakultas Ekonomi Universitas Airlangga. Surabaya, 2006), dan Muslih (Analisis Pengaruh Motivasi terhadap Kepuasan Kerja dan Kinerja Pegawai di PT Sang Hyang Seri (Persero) Regional III Malang, Jurnal Aplikasi Manajemen Vol 10 No 4, 2012) bahwa motivasi ekstrinsik mempunyai pengaruh yang signifikan terhadap kinerja pegawai, namun hasil dari Noermijati (Aktualisasi Teori Herzberg, Suatu Kajian Terhadap Kepuasan dan Kinerja Spiritual Manajer Operasional Penelitian di Perusahaan Kecil Rokok Sigaret Kretek Tangan di Wilayah Malang, Disertasi Pascasarjana Universitas Brawijaya, 2008). Menghasilkan bahwa faktor hygiene tidak berpengaruh langsung terhadap kinerja manajer operasional. Hal ini merupakan variasi dari hasil penelitian terdahulu yang memicu pertanyaan dan akan diteliti dalam penelitian kali ini.

$\mathrm{H} 2$ : Faktor Higienis berpengaruh terhadap Kinerja

\section{KAJIAN TEORI}

\section{a. Motivasi}

Motivasi dapat diartikan sebagai reaksi yang timbul dari dalam diri seseorang karena adanya rangsangan dari luar yang mempengaruhinya Luthans (2011). Motivasi merupakan faktor yang ada dalam pribadi seseorang yang menggerakkan prilakunya untuk memenuhi tujuan tertentu. Motivasi merupakan keadaan kegiatan tertentu guna mencapai suatu tujuan Reksohardiprojo \& Handoko (2003). Teori dua faktor dari Herzberg menurut Usman (2008) menjelaskan bahwa teori dua faktor dikembangkan oleh Herzberg bersama-sama dengan Mausner dan Snyderman. Mereka melakukan penelitian dengan bertanya pada subyek penelitian tentang waktu meraka merasa paling puas terhadap pekerjaannya. Dari penelitian tersebut disimpulkan terdapat dua faktor yaitu faktor pemuas (prestasi, penghargaan, pekerjaan itu sendiri, tanggung jawab, pertumbuhan dan perkembangan) dan faktor kesehatan (supervisi, kondisi kerja, hubungan interpersonal, bayaran dan keamanan, kebijakan perusahaan).

Menurut Hamzah (2010) berpendapat bahwa motivasi adalah dorongan internal dan eksternal dari diri seseorang untuk mengadakan perubahan tingkah laku. Dalam Teori herzberg menyatakan 
ada dua macam motivasi yaitu motivasi internal dan eksternal, sedangkan motivasi eksternal dibagi lagi menjadi dua faktor yaitu motivasional dan higienis.

a. Motivasi Internal

Kebutuhan dan keinginan seseorang akan mendorongnya berprilaku untuk mewujudkan kebutuhan, dan keinginannya. Motivasi internal dapat dikelompokan menjadi dua kelompok yaitu :

1) Motivasi fisiologis yaitu motivasi alamiah seperti lapar, haus dan seks.

2) Motivasi Psikologis seperti motivasi kasih sayang, motivasi mempertahankan diri dan motivasi memperkuat diri.

\section{b. Motivasi Eksternal}

Teori eksternal menjelaskan kekuatan-kekuatan yang ada dalam diri seseorang yang dipengaruhi oleh faktor-faktor internal perusahaan yang dikendalikan oleh manajer, gaji, kondisi kerja, kebijakan kerja, penghargaan dan kenaikan pangkat. Menurut Danang (2015) menyatakan bahwa: "faktor-faktor yang berperan sebagai motivasi terhadap pegawai, yaitu mampu memuaskan dan mendorong orang untuk bekerja dengan baik dalam teori Herzberg"antara lain:

Faktor motivasional meliputi:
a. Prestasi
b. Promosi atau kenaikan pangkat
c. Pengakuan
d. Pekerjaan itu sendiri
e. Penghargaan
f. Tanggungjawab
g. Keberhasilan dalam bekerja
h. Pertumbuhan dan perkembangan pribadi
Sedangkan faktor-faktor higienis meliputi :
a. Gaji
b. Kondisi kerja
c. Status
d. Kualitas supervisi
e. Hubungan antar pribasi
f. Kebijakan administrasi perusahaan
g. Pengertian Kinerja

\section{b. Kinerja}

Kinerja didefinisikan sebagai hubungan antara hasil kerja nyata dengan harapan yang telah ditetapkan sebelumnya atau pembandingan dengan hasil yang dicapai oleh orang lain. Sedangkan Rivai (2009) mengatakan bahwa kinerja merupakan perilaku nyata yang ditampilkan setiap orang sebagai prestasi kerja yang dihasilkan oleh karyawan sesuai dengan perannya dalam perusahaan. Pendapat lain yang dikemukakan oleh Bernadian dan Russel dalam Gomes (2003) mendefinisikan kinerja sebagai hasil dari fungsi suatu pekerjaan atau kegiatan tertentu selama periode waktu tertentu. Berdasarkan uraian tersebut diatas mengungkapkan bahwa dengan hasil kerja yang dicapai oleh seorang karyawan dalam melakukan suatu pekerjaan dapat dievaluasi tingkat kinerja karyawannya, maka kinerja karyawan dapat ditentukan dengan pencapaian target selama periode waktu yang telah dicapai organisasi. Sehingga dapat disimpulkan kinerja organisasi adalah hasil akhir yang diakumulasikan dari seluruh proses dan kegiatan organisasi. Kinerja manajer adalah suatu ukuran tentang bagaimana manajer secara efektif melaksanakan tugas-tugas dan secara efisien menggunakan sumber-sumber untuk mencapai tujuan organisasi melalui pelaksanaan fungsi-fungsi manajemen. 
Mathis \& Jackson (2001) menguraikan bahwa penilaian kinerja (performance appraisal) adalah proses evaluasi seberapa baik karyawan melakukan pekerjaan mereka jika dibandingkan dengan seperangkat standar, dan kemudian mengkomunikasikan informasi tersebut kepada karyawan. Penilaian kinerja juga disebut peningkatan karyawan, evaluasi karyawan, tinjauan kinerja, evaluasi kinerja dan penilaian hasil. Penilaian kinerja digunakan secara luas untuk mengelola upah dan gaji, memberikan umpan balik kinerja dan mengidentifikasi kekuatan dan kelemahan karyawan individual. Bernadian dan Russel (1993) mengutarakan ukuran-ukuran dari kinerja atau hasil kerja seseorang karyawan sebagai berikut.

1. Quantity of work : Jumlah pekerjaan yang dilakukan dalam suatu periode waktu yang ditentukan.

2. Quality of work : kualitas kerja yang dicapai berdasarkan syarat-syarat kesesuaian dan kesiapannya.

3. Job Knowledge : Luasnya pengetahuan mengenai pekerjaan dan keterampilannya.

4. Creativeness : Keaslian gagasan-gagasan yang dimunculkan dari tindakan-tindakan untuk menyelesaikan persoalan-persoalan yang timbul.

5. Cooperation : Kesedian untuk bekerjasama dengan orang lain atau sesama anggota organisasi.

6. Dependability : Kesadaran untuk dapat dipercaya dalam hal kehadiran dan penyelesaian kerja tepat pada waktunya.

7. Initiative : Semangat untuk melakssanakan tugas-tugas baru dan dalam memperbesar tanggungjawabnya.

8. Personal Qualities : menyangkut kepribadian, kepemimpinan, keramah-tamahan dan integritas pribadi.

Secara umum kriteria yang digunakan adalah kualitas, kuantitas, waktu yang digunakan, jabatan yang dipegang, absensi dan ketenangan dalam melaksanakan pekerjaan. Kriteria yang digunakan berbeda antara pekerjaan yang satu dengan yang lain, jadi pengukuran kinerja tergantung pada jenis pekerjaan dan apa yang dihasilkan oleh organisasi atau institusi yang berkepentingan.

Noe R.A et al., (2003) menjelaskan tujuan dari sistem pengelolaan kinerja yang mencakup tiga hal, antara lain:

\section{Tujuan Strategis}

Sistem pengelolaan kinerja harus menghubungkan antara aktivitas karyawan dengan tujuan organisasi. Salah satu cara untuk mengimplementasikan strategi ini adalah dengan terlebih dahulu mendefinisikan hasil, perilaku dan karakteristik karyawan yang selanjutnya digunakan untuk mengeksekusi strategi disertai dengan pengembangan pengukuran kinerja dan sistem umpan balik untuk memaksimalkan potensi karyawan dan memperoleh hasil yang tinggi.

\section{Tujuan Administrasi}

Sebuah organisasi sering kali menggunakan informasi pengelolaan kinerja untuk tujuan pengambilan keputusan administrasi seperti kebijakan kenaikan gaji, promosi jabatan, pemberhentian karyawan dan penghargaan atas kinerja karyawan.

\section{Tujuan Pengembangan}

Tujuan ketiga dari pengelolaan kinerja adalah untuk mengembangkan karyawan agar bisa bekerja secara efektif. Ketika karyawan mulai tidak bekerja sesuai harapan, maka manager harus segera meningkatkan kinerja mereka. Melalui proses evaluasi kinerja dan umpan balik yang diberikan kepada karyawan maka akan ditemukan kelemahan-kelemahan karyawan yang membuat kinerja mereka menurun. 


\section{METODE PENELITIAN}

Dalam penelitian ini, penulis menggunakan metode deskriptif dalam bentuk survey dengan objek penelitian pada Dinas Penanaman Modal dan Ketenagakerjaan Kota Singkawang. Menurut Sujarweni (2015):"Survei adalah penelitian yang dilakukan untuk mengumpulkan informasi yang dilakukan dengan cara menyusun daftar pertanyaan yang diajukan pada responden". Teknik pengumpulan data menggunakan observasi dan kuisioner, yang menjadi populasi dalam penelitian ini adalah seluruh Pegawai pada Dinas Tenaga Kerja dan Penanaman Modal Kota Singkawang yang berjumlah 42 orang. Sedangkan sampel dalam penelitian ini yaitu seluruh populasi dijadikan sampel dengan teknik penentuan sampel menggunakan metode sensus, dan data hasil kuisioner diolah menggunakan SPSS Versi 25.

\section{HASIL DAN PEMBAHASAN}

\section{a. Uji Validitas dan Reliabilitas}

Berdasarkan hasil uji yang telah dilakukan dapat dilihat pada penjelasan berikut yaitu meliputi uji validitas dimana seluruh indikator pada ketiga variable dinyatakan valid dengan signifikansi dibawah 0,05 hasil dapat dilihat pada tabel 2 :

Tabel 2

Uji Validitas

\begin{tabular}{|c|c|c|c|c|}
\hline Variabel & Indikator & R korelasi & Signifikansi & Keterangan \\
\hline \multirow{4}{*}{ Motivasional } & 1 & 0,449 & 0,003 & Valid \\
& 2 & 0,505 & 0,001 & Valid \\
& 3 & 0,798 & 0,000 & Valid \\
& 5 & 0,710 & 0,000 & Valid \\
& 6 & 0,415 & 0,005 & Valid \\
& 7 & 0,439 & 0,004 & Valid \\
& 8 & 0,834 & 0,000 & Valid \\
& 9 & 0,828 & 0,000 & Valid \\
& 10 & 0,753 & 0,000 & Valid \\
& 1 & 0,849 & 0,000 & Valid \\
\hline \multirow{5}{*}{ Higienis } & 2 & 0,476 & 0,001 & Valid \\
& 3 & 0,852 & 0,000 & Valid \\
& 4 & 0,549 & 0,000 & Valid \\
& 5 & 0,555 & 0,000 & Valid \\
& 6 & 0,577 & 0,000 & Valid \\
& 7 & 0,545 & 0,000 & Valid \\
& 8 & 0,600 & 0,000 & Valid \\
& 1 & 0,752 & 0,000 & Valid \\
\hline \multirow{5}{*}{ Kinerja } & 2 & 0,817 & 0,000 & Valid \\
& 3 & 0,860 & 0,000 & Valid \\
& & & \\
\hline
\end{tabular}

Dari hasil uji realibilitas diketahui Alpha Croanbach masing-masing variabel, diperoleh hasil pengujian realibilitas pada tabel 3 berikut: 
Tabel 3

Uji Reliabilitas

\begin{tabular}{|c|c|c|c|}
\hline Variabel & Cronbach Alpha & Nilai Realibilitas & Keterangan \\
\hline Motivasional & 0,763 & 0,60 & Reliabel \\
Higienis & 0,736 & 0,60 & Reliabel \\
Kinerja & 0,826 & 0,60 & Reliabel \\
\hline
\end{tabular}

Pada tabel 3 menunjukan nilai Alpha Cronbach dari keseluruhan variabel adalah lebih besar dari 0,60 dapat disimpulkan bahwa semua variable adalah reliabel karena semua variabel mempunyai nilai Cronbach Alpha diatas 0,60.

\section{b. Uji Asumsi Klasik}

Pada uji asumsi klasik yang pertama adalah uji normalitas, uji normalitas dalam penelitian ini menggunakan uji PP-Plot hasil uji normalitas dapat dilihat pada gambar 1 :

\section{Normal P-P Plot of Regression Standardized Residual}

Dependent Variable: T.v.kinerja

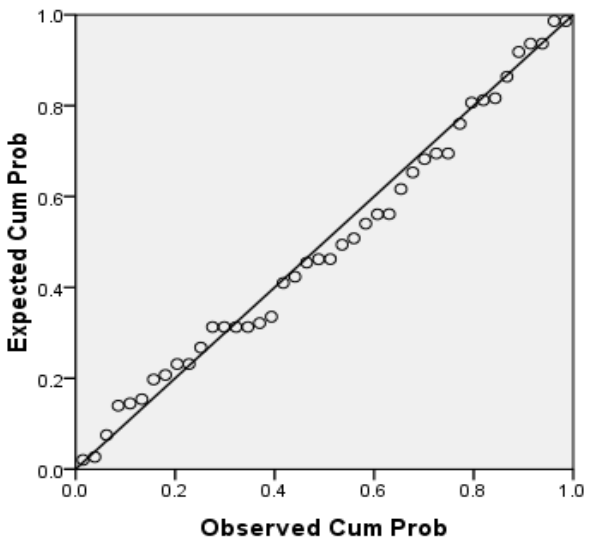

Gambar 1. Uji Normalitas

Hasil pengujian pada gambar 1 menunjukan bahwa indikator variabel menunjukan bahwa titik-titik berada tidak jauh dari garis diagonal. Hal ini berarti bahwa model regresi tersebut sudah terdistribusi normal.

Salah satu metode untuk menguji heteroskedastisitas ini dengan melihat penyebaran dari varians residual. Jika nilai signifikan antara variabel independen dengan nilai residual lebih dari 0,05 maka tidak terjadi Heteroskedastisitas. Untuk mengetahui ada tidaknya gejala Heteroskedastisitas dapat dilihat pada gambar 2: 


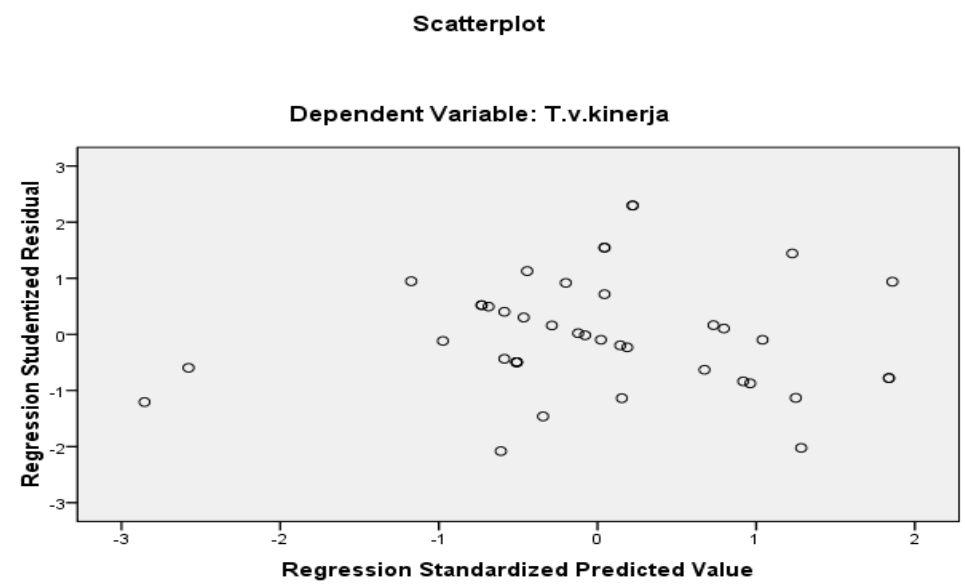

Gambar 2. Uji Heteroskedastisitas

Berdasarkan output Scatterplots diatas diketahui bahwa :

1. Titik-titik data penyebaran diatas dan dibawah atau disekitar angka 0 .

2. Titik-titik tidak mengumpul hanya diatas atau dibawah saja.

3. Penyebaran titik-titik data tidak membentuk pola bergelombang melebar kemudian menyempit dan melebar kembali.

4. Penyebaran data tidak berpola.

Dengan demikian dapat disimpulkan bahwa tidak terjadi masalah Heteroskedastisitas, sehingga model regresi yang baik dan ideal dapat terpenuhi. Uji berikutnya adalah uji Multikolinearitas untuk melihat hasil uji Multikolinearitas maka digunakan asumsi multikolinearitas menyatakan bahwa variabel independen harus terbebas dari gejala multikolinearitas. Dalam uji ini, untuk melihat gejala multikolinearitas dapat dilihat dari hasil Collunearity Statistics. Hasil VIF yang lebih kecil dari 10 menunjukan tidak adanya gejala multikolinearitas.

Tabel 4

Uji Multikolinearitas

\begin{tabular}{|l|c|c|c|}
\hline \multicolumn{1}{|c|}{ Variabel } & Tolerance & VIF & Ket \\
\hline Motivasional & 0,747 & 1,338 & Tidak terjadi \\
Higienis & 0,747 & 1,338 & Tidak terjadi \\
\hline
\end{tabular}

Dari hasil uji pada Tabel 4 dapat dilihat bahwa nilai VIF untuk variabel Motivasional sebesar 1,338 dan variabel Higienis sebesar 1,338 hal itu menunjukan bahwa nilai VIF pada kedua variabel tersebut kurang dari 10. Untuk nilai tolerance pada variabel Motivasional sebesar 0,747 dan variabel Higienis sebesar 0,747 hal itu menunjukan bahwa nilai tolerance pada kedua variabel tersebut lebih besar dari 0,1, maka dapat disimpulkan bahwa model regresi tidak terjadi multikolinearitas.

Uji asumsi klasik yang terakhir adalah Uji Autokorelasi model pengujian yang sering digunakan adalah uji Durbin Watson (uji DW). Pengujian keputusan sebagai berikut :

- $\mathrm{Du}<\mathrm{Dw}<4$, maka H0 diterima, artinya tidak terjadi autokorelasi.

- Dw $<$ Dl atau Dw $>4$, maka H0 ditolak, artinya terjadi autokorelasi.

- Dl $<$ Dw $<$ Du atau 4 - Du $<$ Dw $<4-\mathrm{Dl}$, artinya tidak ada kepastian atau kesimpulan yang pasti. 
Tabel 5

Uji Autokorelasi

\begin{tabular}{|c|c|c|c|c|}
\hline R & R Square & Std.Error & Durbin Watson & Ket \\
\hline 0,627 & 0,394 & 1,232 & 1,466 & Tidak terdapat \\
\hline
\end{tabular}

Berdasarakan Tabel 5 dapat diketahui bahwa DW $(1,466)$ selanjutnya nilai akan dibandingkan dengan nilai tabel signifikan 5 persen jumlah sampel $N=42$ dan jumlah variabel $2(K=2)$. maka diperoleh nilai $\mathrm{Du}=1,606$. Nilai Dw 1,466 lebih kecil dari batas Du 1,606 dan lebih kecil dari (4 du) $4-1,606=2,397$ sehingga dapat disimpulkan tidak terdapat autokorelasi.

\section{c. Uji Hipotesis}

Uji hipotesis yang dilakukan adalah untuk menguji pengaruh variable $\mathrm{X}$ terhadap variable $\mathrm{Y}$ secara parsial (Uji t). Output hasil Uji t dapat dilihat pada tabel 6 berikut:

\section{Tabel 6}

Uji t

\begin{tabular}{|c|c|c|c|}
\hline Variabel & T & Sig & Keterangan \\
\hline Motivasional & 2,704 & 0,010 & Signifikan \\
\hline Higienis & 2,266 & 0,029 & Signifikan \\
\hline
\end{tabular}

\section{Hipotesis 1}

Hasil pengujian diperoleh nilai t untuk variabel motivasional menunjukan nilai thit $=2.704$ dengan nilai signifikan sebesar $0,010<0,05$. Dengan nilai signifikan dibawah 0,05 tersebut menujukan bahwa motivasional memiliki pengaruh signifkan terhadap kinerja pegawai. Hal ini berarti hipotetsis pertama diterima. Dari hasil hipotesis tersebut, motivasional (instrinsik) berpengaruh signifikan terhadap kinerja pegawai pada dinas Penanaman Modal dan Tenagakerja Kota Singkawang berdasarkan hasil uji indikator yang didapatkan hasil karena selain oleh faktor pemuas kebutuhan, prestasi juga diharapkan oleh pegawai dalam pekerjaanya, dengan adanya pengakuan dari atasan maupun dari rekan sekerja akan meningkatkan gairah kerja pegawai yang akan berdampak pada kinerja, komitmen serta tanggung jawab yang tinggi dari pegawai untuk menyelesaikan tugas yang diberikan. Merasa senang atas pekerjaan itu sendiri/ pekerjaan yang diterimanya dengan harapan akan bisa diselesaikan sesuai dengan standar yang berlaku, dengan adanya pengembangan potensi pegawai akan meningkatkan keterampilan yang dimiliki oleh pegawai dan meningkatkan kinerja seperti yang diharapkan dan terakhir selain gaji, penghargaan, promosi atau kenaikan jabatan merupakan salah satu yang paling diharapkan oleh pegawai, dengan terpenuhinya kinerja maka promosi atau kenaikan jabatan juga akan terpenuhi. Hasil penelitian ini sejalan dengan penelitian Akbar (2012) dengan meningkatnya motivasi intrinsik karyawan, maka dapat meningkatkan kinerja karyawan menjadi lebih baik dengan melakukan melakukan upayaupaya perbaikan atas supervisi, gaji, status dan kondisi kerja dari karyawan agar dapat memberikan kinerja yang maksimal. Akan tetapi hasil penelitian ini bertolak belakang dengan penelitian Muslih (2012) bahwa motivasi intrinsik tidak berpengaruh signifikan terhadap kinerja pegawai., yang berarti peningkatan ataupun penurunan tingkat motivasi intrinsik pegawai tidak memberikan pengaruh terhadap kinerja pegawai.

\section{Hipotesis 2}

Hasil pengujian diperoleh nilai t untuk variabel motivasi menunjukan nilai thit $=2.266$ dengan nilai signifikan sebesar $0,029<0,05$. Dengan nilai signifikan dibawah 0,05 tersebut menujukan bahwa faktor higien memiliki pengaruh signifkan terhadap kinerja pegawai. Hal ini berarti hipotetsis kedua diterima. Dari hasil hipotesis tersebut, higien (ekstrinsik) berpengaruh signifikan 
terhadap kinerja pegawai pada dinas Penanaman Modal dan Tenagakerja Kota Singkawang berdasarkan hasil uji indikator yang didapatkan hasil bahwa gaji merupakan salah satu kebutuhan utama yang diinginkan pegawai dalam bekerja. Mereka bekerja karena ingin mempunyai penghasilan sehingga dengan gaji yang mereka dapat setiap bulannya dengan tepat waktu maka semangat mereka bertambah dan setiap akhir tahun mereka mendapatkan tunjangan, lingkungan kerja yang baik pada Dinas Penanaman Modal dan Tenagakerja Kota Singkawang membuat pegawai merasa nyaman dan tenang dalam bekerja, sehingga akan meningkatkan kinerja karyawan baik dalam hal hasil, perilaku maupun sifat kinerja itu sendiri selain itu hubungan kekeluargaanya yang erat membuat pegawai yang bekerja di pada Dinas Penanaman Modal dan Tenagakerja Kota Singkawang tidaklah merasa terbebani dengan pekerjaan yang dilakukan. Selain itu kualitas supervisi serta kebijakan administrasi meliputi (job description, standar operational procedure) yang diterapkan mampu mendorong peningkatan kinerja pegawai. Hasil penelitian ini sejalan dengan penelitian Purnomowati (2006), Muslih (2012), Noermijati (2008), Lee \& Kulviwat (2008) dimana semakin tinggi motivasi ekstrinsik pegawai, maka kinerja pegawai akan semakin tinggi pula. Sebaliknya, semakin rendah motivasi ekstrinsik pegawai, maka kinerja pegawai juga akan semakin rendah yang membuktikan bahwa bahwa motivasi ekstrinsik berpengaruh secara langsung terhadap kinerja pegawai

\section{KESIMPULAN DAN SARAN}

Berdasarkan pada hasil analisis yang telah dilakukan pada penelitian ini, maka dapat ditarik kesimpulan sebagai berikut: Variabel Motivasional (instrinsik), hasil pengujian diperoleh nilai $\mathrm{t}$ untuk variabel motivasi menunjukan nilai thit $=2.704$ dengan nilai signifikan sebsar $0,010<0,05$. Dengan nilai signifikan dibawah 0,05 tersebut menujukan bahwa motivasi memiliki pengaruh signifkan terhadap kinerja pegawai. Jika faktor motivasi mengalami peningkatan maka kinerja juga akan mengalami peningkatan, hal ini berarti faktor motivasi memiliki pengaruh terhadap kinerja.

Variabel Higienis (ekstrinsik), hasil pengujian diperoleh nilai t untuk variabel motivasi menunjukan nilai thit $=2.266$ dengan nilai signifikan sebsar $0,029<0,05$. Dengan nilai signifikan dibawah 0,05 tersebut menujukan bahwa higienis memiliki pengaruh signifkan terhadap kinerja pegawai. Jika faktor higenis mengalami peningkatan maka kinerja juga akan mengalami peningkatan, hal ini berarti faktor higienis memiliki pengaruh terhadap kinerja.

Berdasarkan kesimpulan yang diperoleh dalam penelitian, maka penulis mangajukan saran sebagai pertimbangan bagi Kepala Dinas dan Seluruh Pegawai di Lingkungan Dinas Penanaman Modal dan Tenaga Kerja Kota Singkawang. Disarankan kepada Kepala Dinas untuk lebih meningkatkan perhatian serta memberikan penghargaan kepada pegawai jika hasil kerja yang dihasilkan baik atau bahkan melibatkan pegawai dalam pengambilan keputusan agar pegawai mampu atau mulai belajar bertanggungjawab atas kepercayaan yang dilimpahkan kepadanya dengan harapan akan sangat berdampak postif dan pegawai merasa termotivasi dalam menyelesaikan pekerjaannya. Disarankan kepada Kepala Dinas untuk meningkatkan pengawasan dalam pemberian tunjangan kepada pegawai, agar apa yang diterima oleh pegawai sesuai dengan kinerja yang telah diberikannya kepada Dinas Penanaman Modal dan Tenagakerja Kota Singkawang dengan harapan, pegawai akan merasa bahwa apa yang dilakukannya atau dikerjakannya dengan baik tidak sia-sia.

\section{DAFTAR PUSTAKA}

Akbar, F. Nurtaneo. 2012. Pengaruh Motivasi Intrinsik dan Motivasi Ekstrinsik Terhadap Kinerja Karyawan Pada PT Perkebunan Nusantara XII Surabaya, Jurnal Ilmiah Mahasiswa FEB Universitas Brawijaya, Vol 1 No 2.

Amabile, T.M.Goldfarb, P. and Brackfield, S.C. 1990. "Social Influences on Creativity: Evaluation, Coaction, and Surveillance." Creativity Resources Journal, Vol. 3, pp. 6-21. 
Bernardin, H. John and Russel, E.A. 1993. Human Resource Management, An Experiantial Approach. Mc Graw Hill International Edition, Singapore: Mc Graw Hill Book Co.

Gomes, F.Cardoso. 2003. Manajemen Sumber Daya Manusia. Yogyakarta: Penerbit Andi

Handoko, T. Hani dan Reksohadiprodjo. 2003. Manajemen Sumber Daya Manusia dan Perusahaan. Edisi Kedua. BPFE: Yogyakarta..

Hamzah B. Uno, M. 2010. Teori Motivasi dan Pengukurannya. PT Bumi Aksara. Jakarta

Hayati, K. and Caniago, I. (2012). Islamic Work Ethic: The Role of Intrinsic Motivation, Job Satisfaction, Organi-zational Commitment and Job Perfor-mance. Procedia - Social and Behavioral Sciences 65, $272-277$.

Luviansi, Melti. 2012. Analisis Pengaruh Motivasi Terhadap Prestasi Kerja Melalui Kepuasan Dan Disiplin Kerja Pegawai Studi Pada Universitas Palangka Raya, Jurnal Sains Manajemen Vol 1 No 1.

Luthans, F. 2011. Organizational Beha-vior: an Evidence-based Approach. McGraw-Hill.

Mathis, L., Robert, dan Jackson, H. 2001. "Manajemen Sumber Daya Manusia. Jakarta: Salemba Empat. 102.

Muslih, Basthoumi. 2012. Analisis Pengaruh Motivasi terhadap Kepuasan Kerja dan Kinerja Pegawai di PT Sang Hyang Seri (Persero) Regional III Malang, Jurnal Aplikasi Manajemen Vol 10 No 4.

Noe, R. A., et al., 2003. " uman esource ana ement”. New York: McGraw-Hill Irwin

Noermijati. 2008. Aktualisasi Teori Herzberg, Suatu Kajian Terhadap Kepuasan dan Kinerja Spiritual Manajer Operasional (Penelitian di Perusahaan Kecil Rokok Sigaret Kretek Tangan di Wilayah Malang). Disertasi Pascasarjana Universitas Brawijaya.

Purnomowati, E. 2006. Analisis Pengaruh Motivasi terhadap Kepuasan Kerja dan Kinerja Karyawan dengan Variabel Moderator Komitmen pada Perusahaan Garmen di Surabaya. Jurnal Fakultas Ekonomi Universitas Airlangga. Surabaya.

Songpol Kulviwat. 2008. Korean Workers' Motivation Tools: Commitment and Incentive-Based Motivation and Their Relative Impact on Behavioral Work Outcme. Multinational Business Review,Vol. 16 Iss: 4 pp. 87 - 110.

Sujak, A. 1990. Kepemimpinan Manajer. Jakarta: Rajawali Pers.

Sujarweni, V.Wiratna. 2015. Metodologi Penelitian Bisnis dan Ekonomi. PUSTAKA BARU PRESS. Yogyakarta.

Sunyoto, Danang. 2015. Sumber Daya Manusia. Center for Academic Publishing Service (CAPS). Yogyakarta.

Usman, Husaini. 2008. Manajemen: Teori, Praktek dan Riset Pendidikan. Bumi Aksara. Jakarta

Veithzal, Rivai. 2009. Manajemen Sumber Daya Manusia Untuk Perusahaan Dari Teori ke Praktik, PT Raja Grafindo Persada, Jakarta.

Warr, P.B., Cook, J. D. and Wall, T. D. 1979. "Scales for The Measurement of Some. Work Attitudes and Aspects of Psychological Well-Being”. Jour-nal of Occupational Psychology, Vol. 52, pp. 129-48.

Zapata-Phelan, C.P., Colquitt, J.A., Scott, B.A., \& Livingston, B. 2009. Procedural Justice, Interactional Justice, and Task Performance: The Mediating Role of Intrinsic Motivation. Organizational Behavior and Human Decision Processes, 108: 93-105. 